\title{
Profil Total Lemak dan Protein Hati Puyuh Fase Grower dan Layer
}

The Fat Total and Protein Profile in Grower Phase and Layer Quail Liver Tissue

\author{
A. Mushawwir*, N. Suwarno, R. Permana \\ Fakultas Peternakan Universitas Padjadjaran \\ Kampus Jatinangor Jl. Raya Bandung-Sumedang Km. 21, Sumedang, \\ Jawa Barat, 45363 \\ *Korespondensi E-mail : mushawwir.unpad@gmail.com
}

\begin{abstract}
ABSTRAK
Delapan puluh puyuh berumur 4 minggu telah digunakan dalam penelitian ini untuk mengkaji profil lemak dan protein jaringan hati puyuh fase grower dan layer. Penelitinai ni telah dilaksanakan di Kandang Produksi Ternak Unggas, Fakultas Peternakan dan di Laboratorium Fisiologi Ternak dan Biokimia Fakultas Peternakan Universitas Padjadjaran. Penelitian menggunakan metode eksperimental dan pengambilan sampel dilakukan dengan metode purposif sampling (acak). Data yang diperoleh akan di analisis dengan menggunakan rata-rata hitung, simpangan baku dan uji-T student untuk populasi yang tidak berpasangan. Hasil penelitian menunjukan bahwa terdapat perbedaan antara jumlah kadar lemak jaringan hati pada puyuh fase grower $(27,06 \%)$ dan fase layer $(34,17 \%)$. Jumlah kadar protein jaringan hati pada puyuh fase grower $(78,59 \%)$ dan fase layer $(64,06 \%)$.
\end{abstract}

Kata kunci: Puyuh, hati, Lemak, Protein

\begin{abstract}
Eighty 4 weeks old quail were used in this study to assess the fat and protein profiles of grower phase and layer quail liver tissue. This research was carried out in Poultry Production Station, Faculty of Animal Husbandry and at the Laboratory of Animal Physiology and Biochemistry, Faculty of Animal Husbandry, Padjadjaran University. The research used experimental methods and the sample was taken by purposive sampling method (random). The data obtained will be analyzed using arithmetic mean, standard deviation and Student's T-test for unpaired populations. The results showed that there was a difference between the amount of fat content in the liver tissue in the grower phase $(27.06 \%)$ and the layer phase $(34.17 \%)$. Total protein content of liver tissue in the grower phase $(78.59 \%)$ and layer phase $(64.06 \%)$.
\end{abstract}

Keywords: Quail, Liver, Fat, Protein

\section{PENDAHULUAN}

Puyuh (Cortunix cortunix japonica) adalah ternak unggas penghasil daging dan telur yang berpotensi dikembangkan secara komersial. Dalam percobaan laboratorium, puyuh dipilih menjadi hewan percobaan karena merupakan hewan yang responsif. Puyuh bertelur 
pada umur 41 hari dengan kemampuan memproduksi telur 250-300 butir per tahun (Hartono, 2004).

Sebagai ternak penghasil telur maka manajemen pemberian pakan sangat penting diperhatikan. Pemberian nutrien yang tepat, baik kandungan maupun komposisinya menentukan laju perkembangan organ tubuh puyuh untuk mencapai dewasa tubuh maupun kelamin (sex maturity). Salah satu organ yang bertanggung jawab dalam metabolisme untuk mempersiapkan "sex maturity" adalah hati.

Liver atau hati merupakan salah satu organ penting bagi perkembangan aktifitas reproduksi bagi ternak termasuk puyuh. Metabolisme nutrien (protein, lipid, dan karbohidrat) banyak berlangsung di jaringan hati. Metabolisme ini selain untuk penyedian energi bagi aktifitas hidup pokok, juga untuk perkembangan jaringan hati dan ovarium. Diketahui bahwa perkembangan jaringan ovarium ditentukan oleh vitellogenesis di dalam sel-sel hati. Vitellogenesis merupakan biosintesis prekursor-prekursor pembentukan granula lemak yolk yang berlangsung di dalam hati. Selain lemak juga disintesis kolesterol sebagai prekursor estrogen di ovarium. Estrogen tersebut memegang peranan penting dalam sintesis protein di dalam sel-sel ovarium, oviduk (magnum) dan juga di hati (Stallknecht dkk., 2001; Slimen dkk., 2016; Sjofjan dkk., 2020; Siregar dkk., 2020). Terkait dengan peranan hati dalam biosintesis, telah dilaporkan bahwa regulasi ekspresi gen pada jaringan hati dengan menggunakan sampel jaringan hati angsa menunjukkan bahwa aktivitas ekspresi gen untuk proses metabolik sebesar $22 \%$, oksidasi reduksi $(10 \%)$, organisasi dan biogenesis sel $(8 \%)$, transportasi $(8 \%)$, dan sinyal transduksi (8\%). Aktifitas-aktifitas ekspresi gen tersebut merupakan regulasi ekspresi gen yang menempati proporsi terbesar (Filomeni dkk., 2003; Latipudin dkk 2011; Mushawwir dan Latipuddin, 2013; Hermwan dkk., 2017; Dinana dkk., 2019; Kamil dkk., 2020).

Profil kadar lemak dan protein hati dapat mencerminkan aktifitas biokimia sel-sel hati dalam mempersiapkan ternak puyuh memasuki fase bertelur (Sengenes dkk., 2000; Shinder dkk., 2007; Sahara dkk., 2020ab, Mushawwir dkk., 2020abcd). Melalui hasil pengamatan ini dapat diperoleh informasi dan pertimbangan ilmiah untuk melakukan rekayasa pakan maupun rekayasa faktor-faktor lingkungan lainnya seperti cahaya dalam produksi ternak puyuh.

Berdasarkan uraian sebelumnya maka dalam penelitian ini telah dilakukan kajian dan studi terhadap profil lemak dan protein jaringan hati puyuh fase grower dan layer. 


\section{BAHAN DAN METODE}

\section{Ternak Sampel dan Flok Percobaan}

Delapan puluh ekor puyuh petelur dengan umur seragam (4 minggu) telah digunakan dalam penelitian ini.. Kandang yang digunakan adalah sistem cage, kerangka terbuat dari ram kawat (alas dan sisi). Ukuran kandang adalah $p \times l \times t(100 \times 200 \times 35 \mathrm{~cm})$ dengan ketinggian kandang dan alas lantai $35 \mathrm{~cm}$. Litter akan ditempatkan di bawah kandang tersebut untuk mengurangi pencemaran dari kotoran puyuh

\section{Pengambilan sampel}

Setiap minggu puyuh dipotong untuk diambil jaringan hatinya sebanyak 20 ekor. Pembedahan dilakukan di Laboratorium Fisiologi Ternak dan Biokimia, dengan prosedur pembendahan sesuai dengan protokol pembenahan (Mushawir dkk., 2011, 2012, 2019). Jaringan hati yang telah dikoleksi segera dtimbang beratnya msing-masing.

Selama penelitian ransum yang digunakan adalah ransum komersial komplit berbentuk crumble. Adapun analisis kandungannya sebagai berikut:

Tabel 1. Kandungan Nutrien dan Energi Metabolis Ransum yang digunakan selama Penelitian

\begin{tabular}{|c|c|c|}
\hline No & Zat-zat Makanan & Kandungan \\
\hline 1. & Protein Kasar (\%) & 19,16 \\
\hline 2. & Lemak Kasar (\%) & 3,83 \\
\hline 3. & Serat Kasar (\%) & 4,67 \\
\hline 4. & Kalsium (\%) & 3,17 \\
\hline 5. & Fosfor $(\%)$ & 0,38 \\
\hline 6. & Energi Metabolis (kkal/kg) & 2750 \\
\hline
\end{tabular}

Hasil Analisis Laboratorium Nutrisi Ternak Ruminansia dan Kimia Pakan Ternak, Fakultas Peternakan Universitas Padjadjaran, 2019

\section{Analisis Sampel Jaringan}

Jaringan diekstraksi dengan pelarut lemak. Setelah pelarutannya diuapkan, lemak dapat ditimbang dan dihitung persentasinya. Lima gram sampel telah ditimbang dan dibungkus dengan kertas saring yang bebas lemak, kemudian dipanaskan dalam oven pada suhu $105{ }^{\circ} \mathrm{C}$ selama 12 jam untuk menghilangkan air. Sampel yang telah kering tersebut ditimbang dan dimasukkan kedalam alat ekstraksi soxhlet kemudian diberi pelarut lemak dengan perbandingan $1: 2$. Ekstraksi dilakukan selama 8 jam sampai larutan pelarut lemak dalam ekstraksi soxhlet berwarna jernih. Sampel yang telah terekstraksi lemaknya 
dikeringkan lagi dalam oven selama 12 jam pada suhu $105{ }^{\circ} \mathrm{C}$. Sampel kemudian dikeluarkan dari oven dan ditimbang.

Penentuan kadar lemak, selisih dengan bobot sampel sebelum dan setelah diekstraksi menunjukkan banyaknya lemak yang terkandung kemudian dinyatakan dalam persentasi.

$\%$ kadar lemak $=\frac{\mathrm{Y}-\mathrm{Z}}{\mathrm{X}} \times 100$

Keterangan :

$\mathrm{Y} \quad=$ bobot sampel kering sebelum diekstraksi

$\mathrm{Z} \quad$ = bobot sampel setelah diekstraksi dan dikeringkan

$\mathrm{X} \quad=$ bobot sampel awal

Penentuan kadar protein jaringan telah dilakukan dengan menimbang contoh sampel kering oven sebanyak $\pm 1 \mathrm{~g}$ (dicatat sebagai A g). kemuidan dimasukkan ke dalam labu kjeldahl dengan hati-hati, dan tambahkan 6 gram katalis campuran, dan ditambahkan $20 \mathrm{ml}$ asam sulfat pekat. Dipanaskan dengan nyala api kecil di lemari asam. Bila sudah tidak berbuih lagi distruksi diteruskan dengan nyala api yang besar. Destruksi sudah dianggap selesai bila larutan sudah berwarna hijau jernih, setelah itu dinginkan.

Kemudian dilanjutkan dengan distilasi dengan menyiapkan alat destilasi selengkapnya, dipasang dengan hati-hati, disertai dengan lupa batu didih di dalam labu, serta vaselin dan tali pengaman. Larutan hasil destruksi dipindahkan ke dalam labu didih, kemudian dibilas dengan aquades sebanyak lebih kurang 50 mL. Kemudian dipasang erlenmeyer yang telah diisi denga asam borax 5\% sebanyak $15 \mathrm{ml}$ untuk menangkap gas amonia, dan telah diberi indikator campuran sebanyak 2 tetes. Larutan bahan dari destruksi di kondisikan menjada basa dengan menambah 40-60 $\mathrm{ml} \mathrm{NaOH} 40 \%$ melalui corong samping. Kran corong ditutup segera setelah larutan tersebut masuk ke labu didih. Pemanas bunsen dinyalakan dan dialirkan air ke dalam kran pendingin tegak. Destilasi dilakukan sampai semua $\mathrm{N}$ dalam larutan dianggap telah tertangkap oleh asam borax yang ditandai dengan menyusutnya larutan dalam labu didih sebanyak 2/3 bagian (atau sekurangsekurangnya sedah tertampung dalam erlenmeyer sebanya $15 \mathrm{ml}$ ).

Titrasi dilakuakn terhadap erlenmeyer yang berisi sulingan, bagian yang terendam dalam air sulingan dibilas lebih dahulu. Kemudian titrasi dengan $\mathrm{HCl}$ yang telah diketaui normalitasnya catat sebagai $B$, titik titrasi dicapai dengan ditantai perubahan warna hijau ke 
abu-abu. Catat jumlah larutan $\mathrm{HCl}$ yang terpakai sebagai $\mathrm{C} \mathrm{ml}$. Kadar protein ditentukan dengan formula berikut :

$$
\% \text { Protein Kasar }=\frac{C \times B \times 0.014 \times 6.25}{A} \times 100 \%
$$

\section{Analisis Data}

Analisis statisitika terhadap data yang diperoleh dalam penelitian ini, dilakukan dengan menggunakan Uji Perbandingan T-Student tidak berpasangan. Analisis dan interpretasi data telah dilakukan menggunakan software SPSS IBM 21. Analisis dilakukan dengan derajat kesalahan atau ketidakterimaan respon sampel sebesar $5 \%$.

\section{HASIL DAN PEMBAHASAN}

\section{Profil Lemak dan Protein Jaringan Hati Puyuh Fase Grower dan Layer}

Profil lemak dan protein jaringan hati puyuh fase grower dan layer dapat dilihat pada Ilustrasi 1. Dilihat dari Ilustrasi 1 bahwa konsentrasi lemak relatif meningkat dari minggu ke-4 hingga minggu ke-7. Pada minggu ke-5 konsentrasi lemak cukup tinggi, hal itu dikarenakan lemak juga digunakan untuk proses pematangan folikel. Untuk protein dari minggu ke-4 hingga minggu ke-5 mengalami kenaikan, kemudian begitu memasuki minggu ke-7 ( fase layer) mengalami penurunan. Hal ini sejalan dengan penelitian Jull (1979) yang menyatakan pertumbuhan yang paling cepat pada puyuh periode pertumbuhan dimulai sejak waktu menetas hingga 4-6 minggu kemudian mengalami penurunan. Laju pertumbuhan puyuh jantan dan betina akan menurun setelah berumur 5-6 minggu dan perbedaan kecepatan pertumbuhan antara puyuh jantan dan betina akan terlihat berumur 6 minggu (Adriani dkk, 2008, 2020; Abdullah dkk., 2020).

Ternak unggas berumur dibawah empat bulan dan kurang 4 minggu (pada puyuh) memiliki ovarium dan saluran telur (oviduk) dengan ukuran kecil karena belum berkembang sempurna. Pertumbuhan kelenjar telur dirangsang oleh Follicle Stimulating Hormone (FSH) yang dihasilkan oleh kelenjar pituitary bagian depan. Hormon ini menyebabkan ovarium berkembang dan folikel tumbuh membesar. Ovarium unggas dewasa yang berkembang tersebut mulai mengeluarkan hormon estrogen yang 
menyebabkan terjadi kenaikan kadar kalsium, protein, lemak, vitamin, dan substansi lain dalam darah yang penting untuk pembentukan telur. Ovarium selain menghasilkan hormon estrogen juga memproduksi hormon progesteron yang berfungsi sebagai hormon releasing factor di hipotalamus yang menyebabkan pembesaran Luteinizing Hormon (LH) dari pituitary depan. Hormon LH menyebabkan terlepasnya kuning telur yang tebal masak dari ovarium (Lee dkk., 2014; Jiwandini dkk., 2020; Mistiani dkk., 2020).

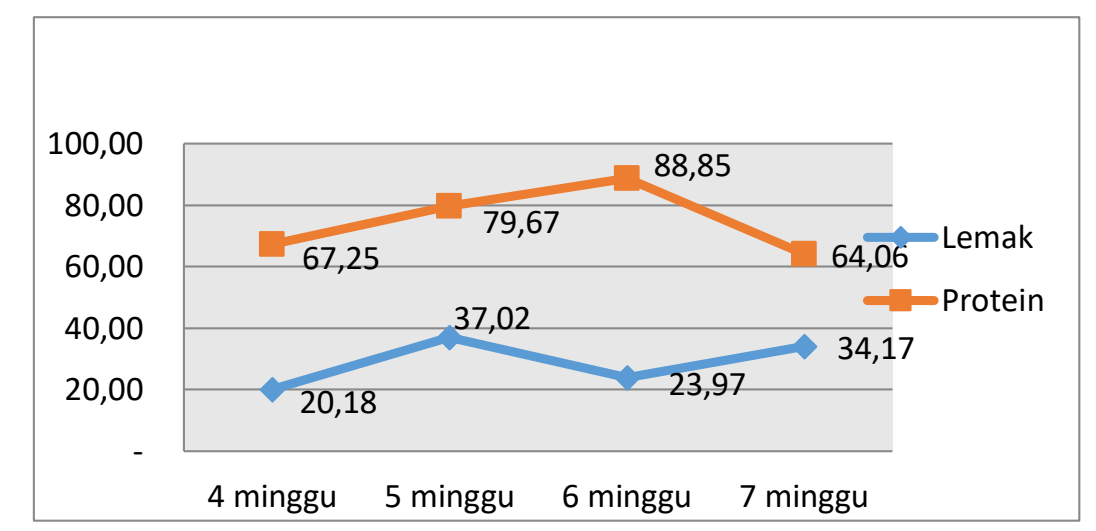

Ilustrasi 1. Profil Lemak dan Protein Jaringan Hati Puyuh Fase Grower hingga Awal Layer

\section{Perbandingan Profil Lemak dan Protein Jaringan Hati Puyuh Fase Grower dan Layer}

Rata- rata hasil pengamatan kadar lemak dan protein jaringan hati puyuh (Coturnix coturnix japonica) fase grower dan layer disajikan pada Tabel 2. Tabel 2 menunjukan rata-rata kadar lemak puyuh fase grower 27,06 \% dan fase layer 34,17 \%. Sedangkan untuk rata-rata kadar protein puyuh fase grower 78,59 \% dan fase layer 64,06 \%. Untuk mengetahui perbedaan nilai lemak dan protein jaringan hati puyuh kedua fase dilakukan uji $\mathrm{T}$ students tidak berpasangan yang sebelumnya dilakukan uji kesamaan varians dari dua fase puyuh tersebut.

Perbandingan rata-rata kadar lemak jaringan hati puyuh fase grower dan layer dapat dilihat pada Ilustrasi 2. Hasil analisis uji rata-rata kadar lemak pada fase grower dan layer dapat dilihat pada Lampiran 4. Rata-rata kadar lemak pada fase grower sebesar 27,06 \% dan fase layer sebesar 34,17 \%. Sama halnya dengan kadar lemak, hasil analisis uji rata-rata kadar protein pada fase grower dan layer dapat dilihat pada Lampiran 8. Rata-rata kadar protein pada fase grower sebesar 78,59 \% dan fase layer sebesar $64,06 \%$. Untuk mengetahui 
sejauh mana perbedaan rata-rata nilai kadar lemak dan protein, telah dilakukan uji kesamaan varian dan uji kesamaan rata-rata.

Tabel 2. Kadar lemak dan protein jaringan hati puyuh (Coturnix coturnix japonica) fase grower dan layer

\begin{tabular}{lcc}
\hline \multirow{2}{*}{ Sampel $(\mathbf{n}=\mathbf{2 0})$} & \multicolumn{2}{c}{ Fase } \\
\cline { 2 - 3 } & Grower & Layer \\
\hline Lemak $(\%)$ & 27,06 & 34,17 \\
Protein $(\%)$ & 78,59 & 64,06 \\
\hline Ratio & $1: 2,90$ & $1: 1,87$ \\
\hline
\end{tabular}

Terlihat dari Ilustrasi 2, bahwa kadar lemak mengalami peningkatan dari fase grower ke fase layer. Hal ini sesuai dengan temuan A.Mushawwir dan D.Latipuddin (2013) bahwa liver ayam dewasa yang sedang memasuki fase bertelur memiliki konsentrasi lipid dua kali lebih tinggi dibandingkan ayam maupun bangsa burung umumnya yang belum dewasa. Pembentukan atau sintesis komponen-komponen yolk (vitellogenesis) berlangsung di dalam hati (Mushawwir dkk., 2019a,b; Sahara dkk., 2020a,b).

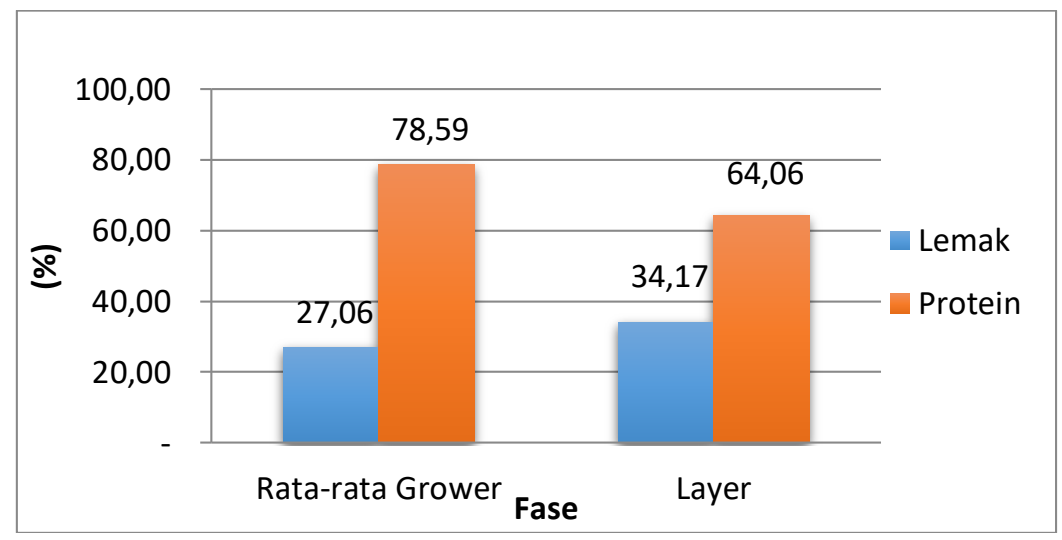

Ilustrasi 2. Perbandingan kadar lemak dan protein jaringan hati puyuh fase grower dan layer

Terkait dengan peranan hati dalam biosintesis, telah dilaporkan bahwa regulasi ekspresi gen pada jaringan hati angsa menunjukan bahwa aktivitas ekspresi gen untuk proses metabolisme sebesar 22\% (Tanuwiria, 2007a,b; Tanuwiria dan Mushawwir, 2020), hal itu 
menunjukan bahwa gen ini memainkan peranan penting dalam pembentukan lemak hati pada angsa serta memainkan peranan penting dalam memediasi metabolisme lipid. Yolk atau kuning telur, komposisi nutrienya terdiri dari lemak dan protein, sedangkan pembentukan lipoproteinnya merupakan proses biokimiawi dari prekursor-prekursor lemak yang disintesis oleh sel-sel hati di bawah control hormone estrogen (Tanuwiria dkk., 2011 dan 2020).

Berbeda halnya dengan lemak, pada Ilustrasi 2 menunjukan konsentrasi protein pada fase grower meiliki kadar yang lebih tinggi dibandingkan pada fase layer. Fungsi utama protein bagi unggas digunakan dalam pertumbuhan dan penggantian jaringan, selain itu berfungsi dalam pembentukan telur, panas, energi dan produksi lemak (anggorodi, 1985).

Pada masa pertumbuhan, broiler harus memperoleh makanan yang banyak mengandung protein, zat ini berfungsi sebagai zat pembangun, pengganti sel yang rusak dan berguna untuk pembentukan telur (Filomeni dkk., 2003; Mushawwir dkk., 2010, Olobatoke dkk., 2011). Sedangkan Adriani dan Mushawwir (2020) menyatakan bahwa, kebutuhan protein per hari untuk broiler yang sedang bertumbuh dibagi menjadi tiga bagian yaitu protein yang dibutuhkan untuk pertumbuhan jaringan, protein untuk hidup pokok dan protein untuk pertumbuhan bulu. Pertumbuhan mencakup pertumbuhan dalam bentuk penambahan volume dan berat jaringan- jaringan tubuh seperti: tulang, jantung, otak, begitu pula jaringan tubuh lainnya (kecuali jaringan lemak) dan. Selanjutnya dinyatakan oleh Yang dkk. (2001) bahwa pertumbuhan adalah suatu penambahan jumlah protein dan zat-zat mineral yang tertimbun dalam tubuh, sedangkan penambahan lema atau penambahan air bukanlah pertumbuhan murni (Adawiah dkk., 2007; Abdullah dkk., 2020; Azizah dkk., 2020).

Berdasarkan uraian sebelumnya dapat dijelaskan bahwa konsentrasi lemak pada hati puyuh mengalami peningkatan dari fase grower menuju layer. Hal tersebut terjadi karena pada fase layer terdapat proses sintesis yolk (vitellogenesis) yang membutuhkan lemak cukup tinggi. Untuk protein mengalami hal sebaliknya, bahwa konsentrasi protein fase grower lebih tinggi dibandingkan fase layer. Suwarno dan Mushawwir (2019) mengemukakan bahwa fungsi utama protein bagi unggas adalah untuk pertumbuhan dan penggantian jaringan. Pada fase grower terjadi proses pertumbuhan, pertumbuhan ini diindikasikan dengan bertambahnya volume dan berat jaringan, sedangkan untuk fase layer penggunaan protein dan lemak digunakan untuk proses pembentukan telur. 


\section{KESIMPULAN}

Berdasarkan hasil pembahasan dan penelitian dapat disimpulkan bahwa perubahan konsentrasi lemak pada jaringan hati puyuh dari fase grower ke fase layer mengalami peningkatan. Konsentrasi lemak jaringan hati puyuh fase grower 27,06 dan fase layer 27,06. Berbeda dengan lemak, konsentrasi protein jaringan hati puyuh mengalami penurunan dari fase grower ke fase layer. Konsentrasi protein jaringan hati puyuh fase grower 78,59 dan fase layer 64,06 .

\section{DAFTAR PUSTAKA}

Abdullah, M.Y., Muhammad, A., Asmara, I.Y., Widjastuti, T., dan Setiyatwan, H. 2020. Studi potensi ekstrak kulit manggis (Garcinia mangostana 1.) yang di suplementasi mineral tembaga dan seng terhadap pemanfaatan ransum ayam sentul. Jurnal Nutrisi Ternak Tropis dan Ilmu Pakan, 2: 51-59.

Adawiah, A., Sutardi, T., Toharmat, T., Manalu, W., Ramli, N., dan Tanuwiria, U.H. 2007. Respons terhadap suplementasi sabun mineral dan mineral organik serta kacang kedelai sangrai pada indikator fermentabilitas ransum dalam rumen domba. Media Peternakan, 30:62-69.

Adriani, L. dan Mushawwir, A. 2008. Kadar Glukosa Darah, Laktosa dan Produksi Susu Sapi Perah pada Berbagai Tingkat Suplementasi Mineral Makro. Fakultas Peternakan Universitas Padjadjaran.

Adriani, L., and Mushawwir, A. 2020. Correlation Between Blood Parameters, Physiological and Liver Gene Expression Levels in Native Laying Hens Under Heat Stress. IOP Conf. Series: Earth and Environmental Science. 466:1-7.

Adriani, L., Rochana. A., Yulianti, A. A., Mushawwir, A., and Indrayani, N. 2014. Profil serum glutamate oxaloacetat transaminase (SGOT) and glutamate pyruvate transaminase (SGPT) level of broiler that was given noni juice (Morinda citrifolia) and palm sugar (Arenga piata). Lucrări Ştiințifice - Seria Zootehnie, 62:101-105.

Azizah, T.R.N., Singgih, D.P., Setiyatwan, H., Widjastuti, T., dan Asmara, I.Y. 2020. Peningkatan pemanfaatan ransum pada ayam sentul yang diberi ekstrak buah mengkudu (Morinda citrifolia) dengan suplementasi tembaga dan seng. Jurnal Nutrisi Ternak Tropis dan Ilmu Pakan, 2:25-34.

Dinana, A., Latipudin, D., Darwis, D., dan Mushawwir, A. 2019. Profil enzim transaminase ayam ras petelur yang diberi kitosan iradiasi. Jurnal Nutrisi Ternak Tropis dan Ilmu Pakan 1:6-15.

Filomeni, D., Katia, A., Rotilio, G., \& Maria, R.C. 2003. Reactive oxygen species-dependent cjun NH2-terminal kinase/c-jun signaling cascade mediates neuroblastoma cell death induced by diallyl disulfide. Cancer Research, 63:5940-5949.

Hernawan, E., Adriani, L., Mushawwir, A., Cahyani, C., \& Darwis, D. 2017. Effect of dietary supplementation of chitosan on blood biochemical profile of laying hens. Pakistan Journal of Nutrition, 16:696-699. 
Jiwandini, A., Burhanudin, H., and Mushawwir, A. 2020. Kadar enzim transaminase (sgpt, sgot) dan gamma glutamyl transpeptidase $(\gamma-g t)$ pada ayam petelur fase layer yang diberi ekstrak pegagan (Centella asiatica). Jurnal Nutrisi Ternak Tropis dan Ilmu Pakan. 2:112-119.

Kamil, K.A., Latipudin, D., Mushawwir, A., Rahmat, D., and Balia, R.L. 2020. The Effects of ginger volatile oil (gvo) on the metabolic profile of glycolytic pathway, free radical and antioxidant activities of heat-stressed cihateup duck. International Journal on Advanced Science, Engineering and Information Technology, 10:1228-1233.

Latipudin, D. dan Mushawwir, A. 2011. Regulasi panas tubuh ayam ras petelur fase grower dan layer. Jurnal Sains Peternakan Indonesia, 6: 77-82.

Lee D.H., Lim, S.R., Ra,S.S., and Kim, J.D. 2014. Effects of dietary garlic powder on growth, feed utilization and whole body composition change in fingerling sterlet sturgeon, Acipenser ruthenus. Asian-Autralas. Journal of Animal Science, 27:1419-1429.

Mistiani, S., Kamil, K.A., dan Rusmana, D. 2020. Pengaruh tingkat pemberian ekstrak daun burahol (Stelechocarpus burahol) dalam ransum terhadap bobot organ dalam ayam broiler. Jurnal Nutrisi Ternak Tropis dan Ilmu Pakan, 2: 42-50.

Mushawwir, A. 2015. Biokimi Nutrisi. Widya Padjadjaran, Bandung.

Mushawwir, A. dan Latipudin, D. 2011. beberapa parameter biokimia darah ayam ras petelur fase grower dan layer dalam lingkungan "upper zonathermoneutral. Jurnal Peternakan Indonesia, 13:191-198.

Mushawwir, A. and Latipudin, D. 2012. Respon fisiologi thermoregulasi ayam ras petelur fase grower dan layer. Proceeding of National Seminar on Zootechniques. 1:23-27.

Mushawwir, A. dan D. Latipudin. 2013. Biologi Sintesis Telur : Aspek Fisiologi, Biokimia dan Molekuler dalam Produksi Telur. Graha Ilmu.

Mushawwir, A., Yong, Y.K., Adriani, L., Hernawan, E., and Kamil, K.A. 2010. The Fluctuation Effect of Atmospheric Ammonia (NH3) Exposure and Microclimate on Hereford Bulls Hematochemical. Journal of the Indonesian Tropical Animal Agriculture, 35:232-238.

Mushawwir, A., Johar Arifin, Darmawan Darwis, Tita Puspitasari, Dewi Sekar Pengerteni, Nunung Nuryanthi, Ronnie Permana. 2020a. Liver metabolic activities of Pasundan cattle induced by irradiated chitosan. Biodiversitas, 21:5571-5578.

Mushawwir, A., Yulianti, A.A., dan Suwarno, N. 2020c. Histologi liver burung puyuh dengan pemberian minyak atsiri bawang putih. Jurnal Ilmu dan Teknologi Peternakan. $8(1): 1-7$.

Mushawwir, A., Yulianti, A.A., Suwarno, N., dan Permana, R. 2020b. Profil metabolit plasma darah dan aktivitas kreatin kinase sapi perah berdasarkan fluktuasi mikroklimat lingkungan kandangnya. J. Veteriner, 21:24-30.

Mushawwir, A., Suwarno, N., \& Yulianti, A.A., 2019a. profil malondialdehyde (mda) dan kreatinin itik fase layer yang diberi minyak atsiri garlic dalam kondisi cekaman panas. Jurnal Ilmu dan Industri Peternakan, 5:1-11.

Mushawwir, A., Suwarno, N., dan Yulianti, A.A. 2019b. Thermoregulasi domba ekor gemuk yang dipelihara pada ketinggian tempat (Altitude) yang berbeda. Jurnal Ilmu dan Industri Peternakan, 5:77-86. 
Mushawwir, A., Suwarno, N., dan Latipudin, D. 2020d. Profil metabolik jalur glikogenolisis puyuh dalam kondisi stres panas dengan pemberian diallyl n-sulfida (dn-s) organic. Jurnal Galung Tropika, 9:48-59.

Mushawwir, A., Suwarno, N., dan Permana, R. 2020e. Profil non-esterified fatty acids (NEFA) dan trigliserida ayam sentul pada sistem pemeliharaan berbeda. Jurnal Ilmu dan Industri Peternakan, 6:14-24.

Mushawwir, A., Suwarno, N., Yulianti, A.A., dan Permana, R. 2019. Dampak pemberian minyak atsiri bawang putih terhadap histologi illeum itik cihateup fase pertumbuhan yang dipelihara sacara ekstensif. Jurnal Peternakan Sriwijaya, 8:35-44.

Nurazizah, N., Nabila, A.L., Adriani, L., Widjastuti, T., dan Latipudin, D. 2020. Kadar kolesterol, urea, kreatinin darah dan kolesterol telur ayam sentul dengan penambahan ekstrak buah mengkudu yang disuplementasi cu dan zn. Jurnal Nutrisi Ternak Tropis dan Ilmu Pakan, 2:9-18.

Olobatoke, R. Y., and Mulugeta, S.D. 2011. Effect of dietary garlic powder on layer performance, fecal bacterial load, and egg quality. Poultry Science, 90:665-670.

Peinado M. J., Ruiz, R., and Echavarri, A. 2012. Garlic derivative propyl propane thiosulfonate is effective against broiler enteropathogens in vivo. Poultry Science, 91:2148-2157.

Ramadhina, I.A., Adriani, L., dan Sujana, E. 2019. Pengaruh pemberian ekstrak daun kepel (stelechocarpus burahol) terhadap kadar kolesterol darah dan telur puyuh (Coturnixcoturnix japonica). Jurnal Nutrisi Ternak Tropis dan Ilmu Pakan, 1:34-40.

Safira, M.L., Kurniawan, H.A., Rochana, A., dan Indriani, N.P. 2019. Pengaruh pemupukan nitrogen terhadap produksi dan kualitas hijauan kacang koro pedang (Canavalia gladiata). Jurnal Nutrisi Ternak Tropis dan Ilmu Pakan, 1:25-33.

Sahara, E., Sandi, S., dan Sari, M.L. 2019. Dampak pemberian tepung bawah putih terhadap profil lipid liver dan plasma darah puyuh yang mengalami cekaman panas. Jurnal Nutrisi Ternak Tropis dan Ilmu Pakan, 1(1):16-24.

Sahara, E., Sandi, S., dan Yosi, F. 2020b. Pengembangan produk telur ayam arab silver (silver brakel kriel) rendah lemak dan kolesterol dengan pemberian kitosan murni dalam ransum. Jurnal Nutrisi Ternak Tropis dan Ilmu Pakan, 2(3):120-126.

Sahara, E., Sandi, S., Yosi, F., dan Alexa, R. 2020a. Pengaruh pemberian kitosan dalam ransum terhadap performa ayam arab silver. Jurnal Nutrisi Ternak Tropis dan Ilmu Pakan, 2:35-41.

Saidah, I.N. dan Mushawwir, A. 2015. Mortalitas embrio dan daya tetas itik lokal (Anas sp.) berdasarkan pola pengaturan temperatur mesin tetas. Jurnal E-Student. 4:5-11.

Sengenes, C., Berlan, M., De Glisezinsky, I., Lafontan, M., and Galitzky, J. 2000. Natriuretic peptides: a new lipolytic pathway in human adipocytes. FASEB Journal, 14, 1345-1351.

Shinder, D., Rusal, M., Tanny, J., Druyan, S., and Yahav, S. 2007. Thermoregulatory Responses of Chicks (Gallus domesticus) to Low Ambient Temperatures at an Early Age. Poult. Sci, 86: 2200-2209.

Siregar, R.H., Latipudin, D., dan Mushawwir, A. 2020. Profil lipid darah ayam ras petelur yang di beri kitosan iradiasi. Jurnal Nutrisi Ternak Tropis dan Ilmu Pakan, 2:1-8. 
Sjofjan, O., Adli, D.N., dan Natsir, M.H., dan Kusumaningtyaswati, A. 2020. Pengaruh kombinasi tepung kunyit (Curcuma domestica Val.) dan probiotik terhadap penampilan usus ayam pedaging. Jurnal Nutrisi Ternak Tropis dan Ilmu Pakan, 2:19-24.

Slimen, B, Najar, T., Ghram, A., and Abdrranna, M. 2016. Heat stress effects on livestock: molecular, cellular and metabolic aspects, a review. Journal of Animal Physiology and Animal Nutrition, 100:401-12.

Stallknecht, B., Lorentsen, J., Enevoldsen, L.H., Low, J.B., Biering Sorensen, H., Galbo, H., and Kjor, M. 2001. Role of the sympathoadrenergic system in adipose tissue metabolism during exercise in humans. Journal of Physiology (London), 536: 283-294.

Suwarno, N., dan Mushawwir, A. 2019. Model prediksi metabolit melalui jalur glikogenolisis berdasarkan fluktuasi mikroklimat lingkungan kandang sapi perah. Jurnal Ilmu dan Industri Peternakan, 5:77-86.

Tanuwiria, U.H. \& Mushawwir, A. 2020. Hematological and antioxidants responses of dairy cow fed with a combination of feed and duckweed (Lemna minor) as a mixture for improving milk biosynthesis. Biodiversitas, 21:4741-4746.

Tanuwiria, U.H. 2007a. Proteksi protein tepung ikan oleh berbagai sumber tannin dan pengaruhnya terhadap fermentabilitas dan kecernaannya (in vitro). J. Agroland, 14:5660.

Tanuwiria, U.H., 2007b. Efek suplementasi kompleks mineral-minyak dan mineral-organik dalam ransum terhadap kecernaan ransum, populasi mikroba rumen dan performa produksi domba jantan. Prosiding Seminar Nasional dan Kongres Asosiasi Ahli Nutrisi. AINI. 1:23-27.

Tanuwiria, U.H., Tasrifin, D., dan Mushawwir, A. 2020. Respon gamma glutamil transpeptidase $(\gamma$-gt) dan kadar glukosa sapi perah pada ketinggian tempat (altitude) yang berbeda. Jurnal Ilmu dan Industri Peternakan. 6:25-34.

Tanuwiria, U.H., Santosa, U., Yulianti, A.A., and Suryadi, U. 2011. The Effect of organic-Cr dietary supplementation on stress response in transport-stressed beef cattle. J. Indon. Trop. Anim. Agric. 36:97-103

Tanuwiria, U.T., Mushawwir, A., dan Yulianti, A.A. 2007. Potensi pakan serat dan daya dukungnya terhadap populasi ternak ruminansia di wilayah kabupaten Garut. Jurnal Ilmu Ternak, 7: 11-16.

Yang, S. C., Saranjit, K.C., Jun-Yan, H., and Theresa, J.S. 2001. Mechanism of inhibition of chemical toxicity and carcinogenesis by diallyl sulfide (DAS) and relate compounds from garlic. The Journal of Nutrition, 1041S-1045S. 